6. Мусіхіна, Л. Звичайник : роман / Лілія Мусіхіна. - К. : Дуліби, 2014. - 252 с.

7. Тихоплав, В. Ю. Кардинальный поворот / В. Ю. Тихоплав, Т. С. Тихоплав. СПб. : ИД «ВЕСЬ», 2004. - 320 с.

Стаття надійшла 08.04.2016 року

УДК 821.161.2+39(477)

Вікторія Кириченко

(Умань, Україна)

\title{
ТРАДИЦІЙНЕ ДОЗВІЛЛЯ УКРАЇНСЬКОЇ МОЛОДІ У ТВОРАХ ГР. КВІТКИ-ОСНОВ'ЯНЕНКА
}

У статті проаналізовано твори Гр. Квітки-Основ'яненка та виявлено й охарактеризовано основні форми дозвілля молоді, щзо побутували у XVIII - XIX ст. $в$ Україні.

Ключові слова: дозвілля, молодь, вечорниці, танці, колядки, Купала, музики.

Кириченко В. Традиционный досуг украинской молодежи в произведениях Гр. Квитки-Основьяненко.

В статье изучены произведения Гр. Квитки-Основьяненко, в них выявлень и охарактеризованы основные формы досуга молодежи, которые были распространены XVIII - XIX вв. в Украине.

Ключевые слова: досуг, молодежь, вечерницы, танць, колядки, Купала, музыка.

Kyrychenko $\boldsymbol{V}$. Traditional Ukrainian youth entertainment in Hr. KvitkaOsnov'ianenko works.

The author of the article analyzed the works of Hr. Kvitka-Osnov'ianenko. The main forms of leisure of youth were identified and characterized. All that existed in Ukrainian the $18^{\text {th }}-19^{\text {th }} \mathrm{cc}$. In the stories of the author were demonstrated the attitude of our ancestors to some entertainment as well as the requirements and prohibitions concerning behavior and punishment for their violation or default.

Keywords: leisure, youth, dances, Carols, Kupala, musicians.

Гр. Квітку-Основ’яненка вважають засновником художньої прози і жанру соціально-побутової комедії в класичній українській літературі. Його творчість не тільки значно вплинула на розвиток вітчизняної літератури, але й дала можливість нашим сучасникам ознайомитися 3 життям українців XVIII - XIX ст., з їхнім побутом і традиціями. Можемо стверджувати, що твори Гр. Квітки-Основ'яненка - це своєрідний посібник з українознавства.

Аналіз творів Гр. Квітки-Основ'яненка дозволив нам виокремити у їх змісті такі форми дозвілля: вечорниці, вулиця, танці, календарні свята (клечальна неділя, Петра, Семена, Пилипа, «Ганнинозачатіє», Великдень 
та поминальний тиждень, мертвецький (навський) Великдень, зимові свята, зокрема колядки). Побічно, без докладного опису згадано дитячі ігри.

Важливо, що у творах письменника відображено ставлення українців до часу, а саме поділ тижня на буденний (робочий), коли не було місця відпочинку, та вільний, який присвячувався співу, забавам, танцям: Через увесь тиждень, по будням, ніхто ї̈ не побачить нігде $і$ ні з ким, хоч $з$ дівчатами чи з молодицями: усе за роботою та по господарству, цілий день рук не поклада. Не видко було ї̈ ні на вулиці, як звичайно дівчатам збиратися та пісеньок співати, і на вечорниці ніколи не ходила; а от вже на ігрищах - на Купала, весною у короводі, у ворона; у хрещзика, - тут вона рада була грати з подругами [3, с. 371-372].

Зазвичай співи, танці, ігри відбувалися на традиційних зібраннях молоді в Україні - вулиця, музики, досвітки, посвітки, вечорниці. Поділ цих зібрань відбувався за часом - досвітки, посвітки, вечорниці - та порою року: навесні - влітку - вулиця, музики, восени - взимку вечорниці, досвітки, посвітки, а також молодь брала активну участь у календарних обрядових дійствах.

«Вечорниці», «досвітки», «посвітки» - це свого роду клуб сільської молоді в Україні, де молоді люди знайомляться одне 3 одним та одружуються. Л. Орел зазначає, що вечорниці починалися від 14 листопада [5]. Тривали вони до 11 години вечора. Кожна частина села, а то й кожна вулиця мала свою хату для вечорниць. Навіть на маленьких хуторах було не менше, як дві хати для вечорниць, бо вважалося, що ходити на ті самі вечорниці рідним братам чи рідним сестрам не годиться ... Коли починався Великий Піст. Вечорниці припинялися - гріх $[1$, c. 29].

Вечорниці не були бездіяльною формою відпочинку і не зводилися до простого співу й пияцтва. Зазвичай дівчата брали із собою роботу вишивали або пряли, хлопці також не сиділи без діла: хтось плів бриля, хтось стругав ложку або шпички для галушок, одночасно, вони роздивлялися дівчат, їх майстерність, обираючи собі дружину. 3 вечорниць молодь поверталася додому парами [5, с. 151-153].

Улітку вечорниць не було, їх замінювала «вулиця» - одна 3 найпоширеніших розваг молоді. Відбувалася вона просто неба. Зазвичай збиралися в заздалегідь визначеному місці - на майдані посеред села, на лузі над річкою чи на леваді.

«Вулиця» починалася від Великодніх свят і тривала все літо - до Семена Станника (14 вересня за новим стилем). «На третій день Великодній свят у корчмі збиралася молодь і обирала отамана і отаманшу, a ще підотамана i підотаманшу. Відтоді починалася вулиця» [2]. Збиралися кожен день, проте 3 початком польових робіт зібрання 
відбувалися тільки у неділю і в святкові дні. «Вулиця» відбувалася весело й жваво: з музикантами, танцями, іграми, співом [1, с. 330].

Гр. Квітка-Основ'яненко у своїх творах зображував щоденне життя українського народу, його радощі i горе, роботу i свято, релігійність, моральні цінності та височінь духу. Цікаво, що в його повістях звучить мотив засудження молодіжних зібрань, який дедалі частіше звучав у проповідях священиків, у ставленні батьків до таких посиденьок, у творах українських письменників.

Усе це автор вкладає в уста Марусі, головної героїні однойменної повісті: А про вечорниці так і не споминай! Було і других дівчат відводить та аж плаче і просить: "Будьте ласкаві, сестрички, голубочки, не ходіте на теє проклятеє зборище! Та там нема ніякогісінького добра; там усе зле та лихеє! Збираються буиімто прясти, та замість того пустують, жартують та вчаться горілочку пити; від матерів курей крадуть та mуди носять, та ще й таке там діється, щчо сором і казати. Чи мало ж то своєї слави загубили, ходячи на тую погань: от хоч би $і$ Явдоха, $i$ Кулина, $і$ Пріська. Адже ж $i$ nіп панотецуь не велить $i$ каже, щуо гріх смертельний туди ходити. Та дивітеся ж і на мене: от я дома більш усіх вас напряду, чим ви ходячи» [3, с. 29].

Недовіра до вечорниць полягала ще й у застереженні від чарів, що їх могли напустити дівчата на парубків, або й страшніших, коли використовувалися вміння місцевої відьми. В українців існувала значна кількість оповідей, бувальщин (і небилиць) про відьомські «поробки» на вечорницях. Про це йдеться в повісті «Конотопська відьма»: Сдиножди, вечору сущу, парубочттво ямам'я $і$ поведома на вечорниці, ідіжеядохом, гуляхом довільно, а пихом без міри, єлико монаху; $і$ єщуе мені, у твердості сушу, ідох у своє містопребиваніє, $i$, не доходящу ми хижсни старої Цимбалихи, внезапну під нозі мої верже ся нічтось; глава моя закружсилися, $i$ аз шатахся $i$ мотахсясімо $i$ овамо, $i$, не могушу ми удержатися, падох, акиклада, i успох, i спах тамонедвижим, акимертв, дондеже возія утро. Сиє ж бисть не іноє, яконавожденієпреокаянной відьми [3, с. 175].

Справді, на вечорницях молодь дозволяла собі інколи дещо зайвого 3 погляду народної моралі. Крім того, за етнографічними даними, у випадку, коли вечорниці закінчувалися досить пізно або розгулялася негода, молодь залишалася спати в тій хаті, де проходило зібрання. I тут усе залежало тільки від дівчат: втримаються вони від спокуси чи піддадуться на парубочі умовляння. Тому деякі дівчата та їхні батьки негативно ставилися до таких посиденьок.

Так, у повісті «Маруся» письменник, описуючи скромність та працьовитість дівчини Марусі, чітко окреслює популярні у XVIII ст. форми молодіжного дозвілля, проте контекст засвідчує негативне 
ставлення народу та автора до вечорниць: ... а далі про Марусину натуру: як вона усіх жахається, щзо ніхто ї̈ не бачив не тільки щуоб на вечорницях або у колядиі, та й на вулищюю, і на Купала, і ні на які ігри не ходить ... [3, c. 34].

Пов’язано це насамперед 3 тим, що молодь на вечорницях вела себе більш розкуто, велися «розмови про новини дня, про головні подї в селі: «той помер, той оженився, а той хату купив. Обговорюються найдивовижніші чутки, яких у наших селах завжди було багато... Все иее перемішане сміхом, дотепними жартами і піснями» [1, с. 33].

Із засудження пустих балачок Гр. Квітка-Основ'яненка розпочинає повість «Козир-дівка»: Нічим ми так не согрішаєм на світі, як язиком, осуджаючи один одного. Де чоловік вулицею, - уже ми й знаємо, куди він іде і зачим; задумався чоловік, - уже ми й знаємо, щзо в нього є на думці. От зараз і судимо: "Як-таки за таким $і$ таким ділом ходити, як-таки так і так думати! Чи се ж гоже? ...» [3, с. 259].

Інше - легковажне - ставлення описує Гр. Квітка-Основ'яненко в повісті «Сердешна Оксана»: На вулицฺі, на вечорницяя, у коляди̧і наша Оксана перед веде; без неї не знали б, ияо і робити.

Мати було почни ї̈ зопиняти:

- Сиди, доню, дома, чого таки бігаєи? Чом не робим? Озьми лишень або пряди, або ший: нічого не вмієи.

Кинеться було до матері на шию, обніма ї̈, иілує, примовляти стане:

- Матусенько, ріднесенька, рибочко, голубочко, перепілочко! Не зопиняй же мене. Я ж собі ше молода; нехай же я погуляю, як та птичка на волі під небесами літає. Буду згадувати своє дівування, щзо я в тебе, як рибонька у річці, гуляла, куди хотіла, туди плавала, так тебе дякувала, щзо ти в мене матусенька жаліслива, добра, пестувала мене... [3, с. 318].

У такому ставленні до розваг можемо передбачити дівоче майбутнє. Легковажна Оксана уже й тоді багато собі дозволяла (про це буде сказано пізніше), тоді як скромна Маруся намагалася бути більше вдома, щоб не забруднити своє ім'я негідною поведінкою.

Цікаво, що участь молоді в гуляннях, пов’язаних із календарною обрядовістю, навпаки, віталася. Однак поведінка юнаків і дівчат у цей період була санкціонована ритуалами, що виконували під спів та які спрямовувалися на забезпечення благополуччя та достатку в родині, громаді. Крім того, існували певні вимоги до виконання пісень. Про це ми дізнаємося 3 невеличкого уривку повісті «Сердешна Оксана»: ... знаєте, щзо при короводах треба співати, так як та сопілочка або тихесенький дзвоник... [3, с. 319].

У творах Гр. Квітки-Основ’яненка нами виявлено забави, в яких молодь брала участь навесні: Великодні свята, грали у «Ворона», «Кострубонька», крім того дівчата водили «короводи», «кривий танок», 
співали веснянок тощо: ... дівчата там у хрещчика грають, кривого танця водять ... Адже усюди дівчата грають, усюди весна [3, с. 367].

У повісті «Щира любов» автор не тільки називає найвідоміші та найулюбленіші ігри, а й описує, як грати в «Кострубонька»: Сяк-так стягнулися. Попереду було усе починають вороном, а тоді вже з піснями підуть; так тепер Галочка каже: «Ні, давайте у кострубонька». Ми розберемо ї̈ думку: у кострубонька як грати, так треба пісню голосно викликати, а далі, як вмре кострубонько, так треба у долошки плескати $[3$, с. 378$]$.

У Великодню суботу, коли дівчата йшли на всенощну службу до церкви, парубки забавлялися таким чином: ... їм треба побіля цувинтаря засідати, та як ітиме купка дівчат, так треба кинутись на них, розпудити їх, ту вщиинути, ту помняти, тій тусана дати ... А так щуе й на извинтарі, і там не без іграшок: де побачать, щзо на рундуках полягали дівчата, так ї $і$ поперекидають; або де купка сидить, то підкрадуться та по-ведмежому $і$ ревнуть ... а ті схопляться, біжать, регочуться, лають ... [3, с. 245].

Улітку, коли молодь збиралася на вулиці, запрошували музик: кобзаря, лірника або троїстих музик, працю яких оплачували парубки.

У повісті «Маруся» Гр. Квітка-Основ’яненко передає той емоційний вибух, буяння енергї молодості, що відбувалося під час танців: Троїсmа музика гра щуо є духу: риплять скрипки, бряжчать изимбали, а замість баса сам скрипник скрізь зуби гуде та прищумокує. От і розколихались наші дівчата: вийшла пара, а там друга, пішли у дрібушки. Ніжкки тупотять, підківками бряжчать, побравшись за рученьки, виворочуються, то вп'ять розійдуться та, як утінки, плавно пливуть, тільки головками поводжують, то вп'ять у дрібушки... Вже ц̌ потомились, вже $i$ хусточками утираються, вже б їм $i$ годi, вже $i$ другим хочеться потанцңювати ... так щуо ж бо? Музика гра та й гра! Вже одна з дівчат, Одарка Макотрусівна, ледве ноги волочить, піт з неї так $i$ тече, притьмом просить музику: «Та годі-бо, дядьку!.. Та перестаньте-бо ... ось уже не здужаю!...» Та щуо ж? Музика гра та й гра! ... Далі скрипник закінчив і пити скрипочкою попросив... От дівчатам годі, поклонились музиці і пішли до гурту [3, с. 32].

Літні забави описані також в уже згадуваній повісті «Сердешна Оксана»: Oтсе ж тільки щзо весна настає $і$ сонечко позлизує сніг де з яких горбиків на пісну, вже Оксана $і$ зібрала свою команду: шатнуласьмотнулась з кіния в кінецьь, веде низку дівчат і приговорює: "Та чого ви будете сидіти по хатам? Бог дає весну, сонечко пригріва, вітерецьь тепленький, годі вам по запічкам тулитися. Не обридла вам зима? Не докучило киснути у хаті? Бедете старі, тогді щзе належитеся до печам, нагримаєтесь $з$ мужиками, налаєтесь 3 дітворою. А чим будете 
згадувать свої молодії літа. А бодай вам весело було! (Се вже в гнї усім $i$ завсегда така лайка була). Ануте лишень, побіжімо!.. А берітеся $у$ хрешика, у ворона, поведем кривого тания, коровода, кострубонька, $у$ жони». Зараз попарувала усіх. Все усі дівчата гарні, усі придбані, усі повиряджувані... [3, с. 318].

Автор через ставлення дівчат до забав та ігор розкриває характери героїнь. Змальовуючи Марусю, Гр. Квітка-Основ'яненко говорить про неї лагідно, ніжно, відчувається симпатія автора до своєї героїні: ... як вийде, то щуо і твоя панночка! Іде як павичка, не дуже по усім усюдам розгляда, а тільки дивиться під ноги. Коли з стариим себе зострілась, зараз низенько поклонилась та й каже: хоч би то мала дитина була, то вже не пройде просто, усякому поклониться $і$ ласкаво заговорить. А шуоб який парубок та посмів би ї̈ зайняти? Ну-ну, не знаю! Вона й не лаятиметься, i ні слова й не скаже, а тільки подивиться на нього так пильно, та буцім $i$ жалібно, і сердитенько ... так хоч би який був, то зараз шапку з голови схопе, поклонивсь звичайненько, і ні пари з уст не мовить, і відійде дальи. $O$, там вже на все село була і красива, і розумна, і багата, звичайна, та ще ж к тому тиха, і смирна, і усякому покірна [3, с. 28].

Марусю не можна було впросити піти з подругами погуляти, на всі материні умовляння відповідала: «Лучче я, - каже, - на mе місие, упоравиись, та ляжу спати і зате ранше устану, заміню твою старість: обідати наварю і батькові у поле понесу. А на вулиці щзо я забула? Іграшки mа пустота, та гляди, станеться, хоч $і$ не зо мною, хоч $і$ аби з ким, яка причина, та опісля і страчно відвічати за те одно, чуо й я там була!» [3, c. 29].

Коли читаємо про Оксану, відчуваємо якесь шаленство емоцій і ніякої відповідальності, турботи про матір, прагнення працювати: $O m i$ попарувались дівчата у хрещика; от і гроби стали ... та й чкурнули ... фіть-фіть! Не родився той чоловік, хто б Оксану піймав!..

Набігалась у хрешика, виморила усіх, давай короводи водити! Повела кривого тания, то щуо другі дівчата! Ïx $i$ не видно за нею. Як зірочка вечірня меж усіма зірками; як утінка по воді пливе, та вихиляється, та головкою поводить, та веселенько на усіх погляда ... а як заведе пісеньок, знаєте, щуо при короводах треба співати, так як та сопілочка або тихесенький дзвоник ... Усі прочі співають на увесь рот, а вона і губоньок не роззіва, та ї̈ голосочок чуть від усіх, щ⿻о так за серизе $і$ бере .. усе б слухав ... [3, с. 319].

Окрім згаданих, існував ще один вид дозвілля української молоді ярмарок. Гр. Квітка-Основ'яненко 3 ніжністю та гумором описує це дійство: ... дівчата зібралися іти на ярмарок, бо усе піджидали, шуоб порідшало народу на місиі; а то як у тісноті, так думали, щзо їх не так $i$ розглядають. Ось і тягнеться низка ї, та усе на підбор: одна від другої 
кращуа. Порозряджувані так, щуо господи! [3, с. 19]. Дівчата одягали найкращі вбрання «в самих баєвих червоних юпках, щуо так, як мак, цзвіте. Скиндячки на головах усе по-харківськи положені, коси у дрібуики позаплітувані $і$ жовтими гвоздиками та барвінком позаквітчувані; $y$ сорочок $і$ рукава, і ляхівки повишивані та повимережсувані; на шиях намиста у кожної разків по десять, коли щуе не більш, - аж голову гне! Золоті дукати та срібні хрести так і сяють; плахти картащькі, запаски $i$ шовкові, $і$ колісчасті, пояси каламайкові; усі, як одна, у червоних черевичках $i$ у білих та у синіх панчішках [3, с. 19]. Автор запитує в читача: «А за ділом же вони й вийшли?» і сам же дає відповідь, ніби висміюючи дівочі хитрощі: «А як же? Витрішків купувати, та щуоб чи не пожартують парубки з ними» [3, с. 19].

Пригадаймо, що в іншій повісті - «Маруся»- саме в подорожі на ярмарок Маруся та Василь зізналися один одному у своїх почуттях [3, c. 44-51].

Парубки не відставали від дівчат: ... щевчики, кравчики, ковалі, свитники, гончарі $i$ зо всякого ремества бурлацтво, наньмити від хазяйства, батькові сини - зібралися на ярмарок погулять. Іщче зранку, хто попродав свій товар, а хто покупивши чого кому треба $i$ попивии могоричі, тепер, попідголювавшись любенько, понадівали хто нову свиту, хто китаєву юпку, хто щуе батьківський хоч $і$ старий, та жупан, попідперізувавшись шпетненько хто каламайковим, а хто й суконним поясами, у тяжинових итанях, понадівали на підголені голови шапки козацькі з решетилівських смушків то з червоними, то з зеленими, то з синіми вериками... ідуть лавою, з боку на бік перевалюються, руками розмахують, люльки тягнуть та, щуо э голосу, ажскривляться, та жмуряться, співаючи московські пісні: «При далінусиі стояла»; $i$ де йдуть, то так від них люди й розступаються, бо вже не попадайсь ӥм на дорозі ніхто .... Нікому нема розбору, не вважсають нікого, так усякого прямо лавою $і$ пруть, $і$ мнуть, $i$ з ніг валяють; а самі й байдуже: неначе й не бачать нічого, й буцімтто не вони.

Отсе-то вони, зуздрівии дівчат, потягнули за ними, щуоб так стіною на них $i$ наперти; а як вони розбіжаться, так тут $i$ ловити, $i$ пожартувати, і поженихатись ... Звісно молодецььке, парубоцььке діло! [3, c. 21].

Отже, мета відвідин ярмарку - та ж сама, що й участь у вечорницях, вулиці, музиках - знайти собі пару та вийти заміж.

Аналіз творів Гр. Квітки-Основ’ яненка засвідчує, що автор відобразив ті форми дозвілля української молоді, які побутували в його час, засвідчив ставлення наших предків до тих чи інших розваг, а також вимоги та заборони щодо поведінки, що висувалися до дівчат та покарання за їх порушення або невиконання. 


\section{СПИСОК ВИКОРИСТАНӦ̈ ЛІТЕРАТУРИ}

1. Воропай, О. Звичаї нашого народу : Етнографічний нарис : у 2 т. Т. 1 / О. Воропай. - Мюнхен : Українське видавництво, 1958. - 308 с.

2. Записано від Шевчук Тамари Василівни, 1944 року народження, с. Косенівка Уманського району Черкаської області.

3. Квітка-Основ' яненко, Гр. Твори : у восьми томах. Т. 3 : Оповідання та повісті / Гр. Квітка-Основ'яненко. - К. : Дніпро, 1969. - 509 с.

4. Молодик. - Харків - 1844. - № 3. - С. 241.

5. Українська родина. Родинний і громадський побут / упоряд. Л. Орел. - К. : Вид-во імені Олени Теліги, 2000. - 423 с.

Стаття надійшла 06.04.2016 року

УДК 821.161 .2

Тетяна Лопушан

(Умань, Україна)

\section{РУСТИКАЛЬНИЙ ДИСКУРС ТВОРЧОСТІ Т. ГАЛІПА}

Стаття присвячена аналізу особливостей побутування рустикального дискурсу у творчості західноукраїнського письменника $і$ громадського діяча Теодота Галіпа. Він належсть до числа тих українських патріотів, завдяки яким здійснювалися «малі кроки» до поліпшення становища селянства. У повісті «Панки i підпанки» Т. Галіп робить вдалу спробу художньої рецепції своїх суспільно-політичних поглядів крізь призму здобутого в ході революиійних подій особистого досвіду. Письменник витворює яскраву галерею типів особистостей, щуо належать до різних сочіальних $i$ начіональних прошарків буковинського суспільства, однак так чи інакще пов'язані із селом, його проблемами і неминучими трансформаціями перед викликами сучасності.

Ключові слова: рустикальний дискурс, повість, художня рецепція, Т. Галіп, типологія образів.

Лопушан Т. Рустикальный дискурс творчества Т. Галипа.

Статья посвящена анализу особенностей проявления рустикального дискурса в творчестве западноукраинского писателя и общественного деятеля Теодота Галипа. Он принадлежит к числу тех украинских патриотов, благодаря которым осуществлялись «малье шаги» к улучшению положения крестьянства. Повесть «Панки и подпанки» Т. Галипа - это удачная попьтка художественной рецепџии общественно-политических взглядов писателя сквозь призму полученного в ходе революционных событий личного опьта. Писатель создает яркую галерею типов личностей, принадлежащчих $\kappa$ разным социальным и нацииональньх слоям буковинского общества, однако так или иначе связанных с селом, его проблемами и неизбежными трансформаџиями перед вызовами современности.

Ключевые слова: рустикальный дискурс, повесть, художественная рецепция, Т. Галип, типология образов. 